\title{
STRATEGIES FOR VALIDATING SATELLITE SOIL MOISTURE PRODUCTS USING IN SITU NETWORKS: LESSONS FROM THE USDA-ARS WATERSHEDS
}

\author{
Michael H. Cosh ${ }^{1}$, Thomas J. Jackson ${ }^{1}$, Patrick Starks ${ }^{2}$, David Bosch ${ }^{3}$, Chandra Holifield Collins ${ }^{4}$, \\ Mark Seyfried ${ }^{5}$, John Prueger ${ }^{6}$, Stan Livingston ${ }^{7}$, Rajat Bindlish $^{1}$ \\ ${ }^{1}$ USDA-ARS-Hydrology and Remote Sensing Laboratory, Beltsville, MD \\ ${ }^{2}$ USDA-ARS-Grazinglands Research Laboratory, El Reno, OK \\ ${ }^{3}$ USDA-ARS-Southeast Watershed Research Laboratory, Tifton, GA \\ ${ }^{4}$ USDA-ARS-Southwest Watershed Research Center, Tucson, AZ \\ ${ }^{5}$ USDA-ARS-Northwest Watershed Research Laboratory, Boise, ID \\ ${ }^{6}$ USDA-ARS-National Laboratory for Agriculture and Environment, Ames, IA \\ ${ }^{7}$ USDA-ARS-National Soil Erosion Research Laboratory, West Lafayette, IN
}

\begin{abstract}
There are a variety of soil moisture station designs and networks deployed throughout the world, each with varying applications and uses. For the purpose of satellite validation of soil moisture products, a dense network of soil moisture networks are required with soil moisture sensors at the near surface $(\sim 5 \mathrm{~cm}$ or less) to correspond to the satellite footprints and signals. The USDA- Agricultural Research Service operates a collection of soil moisture networks as a part of the Long Term Agro-ecosystem Research (LTAR) network to this end. These networks have been used to validate products from AMSR-E, SMOS, Aquarius, and SMAP. A review of these results and a synopsis of successful scaling strategies are discussed.
\end{abstract}

Index Terms - Soil Moisture, Validation, Networks, Satellite Products,

\section{INTRODUCTION}

Satellite remote sensing of soil moisture became mature with the launch of the Aqua satellite, which carried the Advanced Microwave Scanning Radiometer (AMSR-E), in 2002. To provide a set of validation data points, the USDA Agricultural Research Service instrumented four of their long-term experimental watersheds with soil moisture and soil temperature sensors in tandem with established precipitation networks [1]. These watersheds, shown in Figure 1, were distributed across a diverse set of land cover conditions, with Walnut Gulch (Arizona) representing semiarid landscape, Little River (Georgia), representing a humid cropland, Little Washita (Oklahoma) representing sub- humid cropland, and rangeland, and Reynolds Creek (Idaho), representing semi-arid mountainous rangeland. These watershed networks were established originally as precipitation networks; therefore, the distribution in space of the stations was not optimized to represent soil moisture, but rather capture the variability of the precipitation. For example, Walnut Gulch has a uniform distribution of stations across the network to capture the small convective events that frequently occur in southeastern Arizona. In Reynolds Creek, the precipitation network has a greater number of stations deployed in the mountainous areas to capture the orthographic variation in snowfall amount. This type of deployment makes it challenging to scale the network to a remote sensing footprint, which is approximately $25-50 \mathrm{~km}$ in scale. Beginning in 2007, additional networks began to be deployed to address additional missions which were in the planning stages, including the Soil Moisture Ocean Salinity (SMOS) mission [2]. These networks included the Fort Cobb (Oklahoma) watershed, which included irrigated cropland, Saint Joseph's Watershed (Indiana), mixed cropland, and South Fork (Iowa), which is dominated by corn and soybean cropland. Each of these watershed networks uses the Stevens Water Hydra Probe at a $5 \mathrm{~cm}$ depth with some sites providing additional depths for further modeling. These networks alone would not be sufficient to provide validation data, unless there was some calibration and verification that the networks provide an accurate estimate of the large scale soil moisture average for satellite validation. Therefore, various strategies needed to be developed and implemented at each watershed to fully qualify these locations for inclusion in the satellite cal/val programs. 


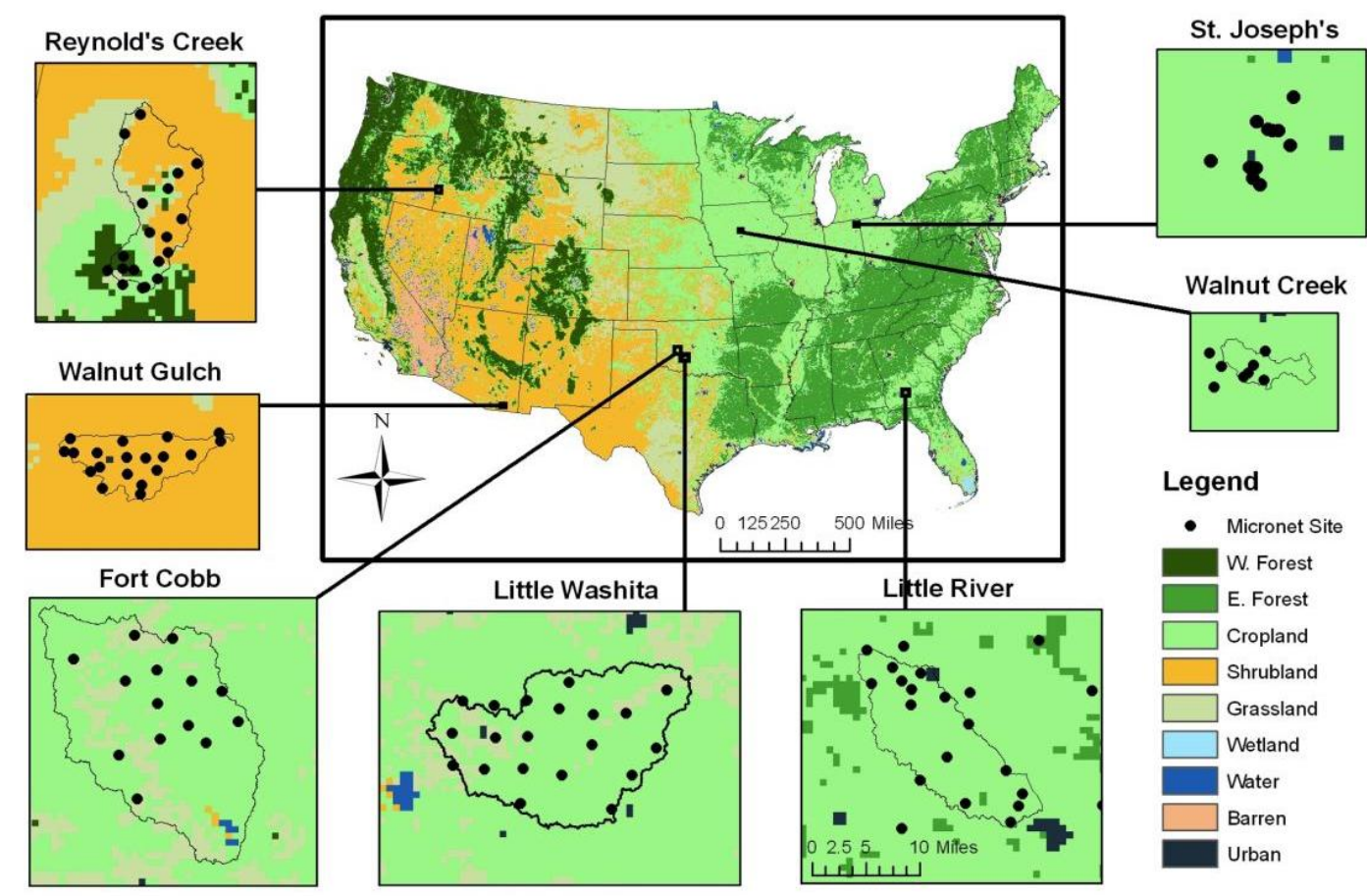

Figure 1: ARS watersheds with a land cover classification color scheme

\section{METHODOLOGY OF VALIDATION}

A critical element of a watershed program is a validation of the measurements being made to assure that they are accurate. For soil moisture, this involves calibration of the sensors, which are installed in the soil. This will account for sensor variation, but it is also necessary to scale the local measurement to the surrounding area, if the data is to be used in a remote sensing validation program. There are several methods of scaling in situ data. The most common is conducting an intensive field experiment with field samplers and synchronous aircraft flights of an instrument similar to the satellite instrument in question. There is a long history of soil moisture experiments with this design, including Soil
Moisture Experiments in 2002 (SMEX02), 2003 (SMEX03), and 2004 (SMEX04), which focused on the AMSR-E instrument [3]-[5]. The CANEX-SM10 experiment in 2010 [6]-[7] focused on validating the SMOS instrument, and the SMAP Validation Experiments in 2015 and 2016 (SMAPVEX15, 16) were coordinated with the SMAP instrument. These experiments provided significant validation of in situ network accuracy and representativeness. Another methodology involves the regular sampling of soil moisture samplers with broad sampling throughout the season of interest (usually summer). One such campaign was conducted in support of the South Fork network in 2014, which established an error less than $0.04 \mathrm{~m}^{3} / \mathrm{m}^{3}$ for several SMAP product pixels. Another method of scaling is by deploying additional temporary

Table 1: Description of USDA ARS Experimental Watersheds with dominant features for each.

\begin{tabular}{l|lllll}
\multicolumn{1}{c|}{ Watershed Name } & Established & \# of Stations & Topography & Landscape & Size $\left(\mathrm{km}^{2}\right)$ \\
\hline Walnut Gulch, Arizona & 2002 & 19 & Rolling & Rangeland & 148 \\
Reynolds Creek, Idaho & 2002 & 19 & Mountainous & Rangeland & 238 \\
Little Washita, Oklahoma & 2002 & 20 & Rolling & Rangeland/Wheat & 610 \\
Little River, Georgia & 2002 & 29 & Flat & Row Crop/Forest & 334 \\
Fort Cobb, Oklahoma & 2007 & 15 & Rolling & Row Crop & 813 \\
Saint Joseph's, Indiana & 2009 & 15 & Flat & Row Crop & 300 \\
South Fork, Iowa & 2013 & 20 & Flat & Row Crop & 625
\end{tabular}


Table 2: Summary of satellite validation RMSE results for the ARS experimental watersheds.

\begin{tabular}{|c|c|c|c|c|c|}
\hline Watershed Name & $\begin{array}{l}\text { AMSR-E } \\
\text { RMSE, } \\
\text { in } \mathrm{m}^{3} / \mathrm{m}^{3}\end{array}$ & $\begin{array}{l}\text { SMOS } \\
\text { RMSE, } \\
\text { in } \mathrm{m}^{3} / \mathrm{m}^{3}\end{array}$ & $\begin{array}{l}\text { Aquarius } \\
\text { RMSE, } \\
\text { in } \mathrm{m}^{3} / \mathrm{m}^{3}\end{array}$ & $\begin{array}{l}\text { SMAP } \\
\text { ubRMSE, } \\
\text { in } \mathrm{m}^{3} / \mathrm{m}^{3}\end{array}$ & $\begin{array}{c}\text { Network } \\
\text { Accuracy, } \\
\mathrm{m}^{3} / \mathrm{m}^{3}\end{array}$ \\
\hline Walnut Gulch, Arizona & 0.025 & 0.024 & - & 0.031 & $\sim 0.01 \mathrm{~m}^{3} / \mathrm{m}^{3}$ \\
\hline Reynolds Creek, Idaho & 0.040 & 0.039 & - & 0.042 & TBD \\
\hline $\begin{array}{c}\text { Little Washita, } \\
\text { Oklahoma }\end{array}$ & 0.045 & 0.036 & 0.031 & 0.025 & $\sim 0.01 \mathrm{~m}^{3} / \mathrm{m}^{3}$ \\
\hline Little River, Georgia & 0.048 & 0.048 & 0.030 & 0.027 & $<0.03 \mathrm{~m}^{3} / \mathrm{m}^{3}$ \\
\hline Fort Cobb, Oklahoma & - & - & - & 0.031 & $<0.03 \mathrm{~m}^{3} / \mathrm{m}^{3}$ \\
\hline Saint Joseph's, Indiana & - & - & - & 0.042 & TBD \\
\hline South Fork, Iowa & - & - & - & 0.045 & $\sim 0.03 \mathrm{~m}^{3} / \mathrm{m}^{3}$ \\
\hline
\end{tabular}

network stations to increase the number of samples of calibrated sensors, providing a better estimate of large scale soil moisture distributions. This has been conducted in coordination with large scale field experiments, such as CANEX-SM10, SMAPVEX12, SMAPVEX15, and SMAPVEX16, as well as standalone experiments in New York and Tennessee [8]. These three methodologies all contribute valuable information to the veracity and accuracy of a soil moisture network estimate.

\section{RESULTS OF VALIDATION}

Data from these watersheds have been compared to that of various satellites for available timeframes, depending on the satellite mission. Table 2 contains a summary of the published results of these network comparisons to the largescale products. The overall accuracy of the AMSR-E products were less than $0.05 \mathrm{~m}^{3} / \mathrm{m}^{3}$ RMSE [1], while the RMSE for SMOS was less than $0.04 \mathrm{~m}^{3} / \mathrm{m}^{3}$ [9]. Each of these has a nominal footprint of $40 \mathrm{~km}$ and have similar performance metrics. The Aquarius soil moisture product has a nominal footprint of $100 \mathrm{~km}$ therefore only two watersheds were of sufficient size and homogeneity to provide validation data [10]. SMAP is similar to SMOS in both footprint and frequency (L-band) and had similar performance metrics [11]-[12]. Each of these missions were able to achieve their performance goals with the inclusion of ARS watersheds as a part of their validation program.

Critical to the incorporation of these networks into a validation program however is some understanding of the accuracy and quality of the network data. The first validation experiment on one of these networks was conducted in 2003, during the SMEX03 experiment, which established the accuracy of the Little Washita network to within $0.01 \mathrm{~m}^{3} / \mathrm{m}^{3}$ of the overall domain average [4]. This was followed up in 2004 where the Walnut Gulch network was validated to within $0.01 \mathrm{~m}^{3} / \mathrm{m}^{3}$ as well [5]. Other network validations were conducted and are listed in Table 2. Network deployments have aided in other network validations with deployments as short as 3 months and as long as 12 months [8].

\section{CONCLUSION}

Network validation is a critical element to satellite validation programs, but quality control is essential to ensure the estimate represents the entire domain. Field experiments are a key tool to provide scaling data for a network, but as instrumentation evolves, temporary networks have become more useful for scaling activities.

\section{REFERENCES}

[1] Jackson, T. J., M. H. Cosh, R. Bindlish, P. J. Starks, D. D. Bosch, M. S. Seyfried, D. C. Goodrich, M. S. Moran, "Validation of Advanced Microwave Scanning Radiometer soil moisture products," IEEE Trans. Geosci. Remote Sens., 48(12): 4256-4272, 2010 .

[2] Njoku, E.G., T.J. Jackson, V. Lakshmi, T.K. Chan, and S.V. Nghiem, "Soil moisture retrieval from AMSR-E," IEEE Trans. Geosci. Remote Sens. 41: 215-229, 2003.

[3] Cosh, M. H., T. J. Jackson, R. Bindlish, J. Prueger, "Watershed scale temporal persistence of soil moisture and its role in validating satellite estimates," Remote Sens. Environ., 92(4): 427-435, 2004.

[4] Cosh, M. H., T. J. Jackson, P. J. Starks, G. C. Heathman, "Temporal stability of surface soil moisture in the Little Washita River watershed and its applications in satellite soil moisture product validation,” J. Hydrol., 323(1-4): 168-177, 2006.

[5] Cosh, M. H., T. J. Jackson, M. S. Moran, R. Bindlish, "Temporal persistence and stability of surface soil moisture in a semi-arid watershed," Remote Sens. Environ., 112(2): 304-313, 2008.

[6] Magagi, R., A. A. Berg, K. Goita, S. Belair, T. J. Jackson, B. Toth, A. Walker, H. McNairn, P. E. O'Neill, M. Moghaddam, I. Gherboudj, A. Colliander, M. H. Cosh, J. Belanger, M. Burgin, J. Fisher, S. -B. Kim, L. P. Rousseau, N. Djamai, J. Shang, A. Merzouki, "Canadian Experiment for Soil Moisture in 2010 
(CanEx-SM10): Overview and Preliminary Results," IEEE Transactions of Geoscience and Remote Sensing, 51(1):347-363, 2012.

[7] Cosh, M.H., T. J. Jackson, C. Smith, B. Toth, A. Berg, "Validating the BERMS in situ soil water content data record with a large scale temporary network", Vadose Zone Journal, 12(2), doi:10.2136/vzj2012.0151, 2013.

[8] Coopersmith, E., M. H. Cosh, J. E. Bell, V. Kelly, M. Hall, M. A. Palecki, M. Temimi, "Deploying temporary networks for upscaling of sparse network stations", International Journal of Applied Earth Observations and Geoinformation, 52:433-444, 2016.

[9] Jackson, T. J., R. Bindlish, M. H. Cosh, T. Zhao, P. Starks, D. D. Bosch, M. Seyfried, M. S. Moran, D. C. Goodrich, Y. H. Kerr, D. Leroux, "Validation of Soil Moisture and Ocean Salinity (SMOS) soil moisture over watershed networks in the U.S.," IEEE Trans. Geosci. Remote Sens., 99:1-14, 2011.

[10] Bindlish, R., T. J. Jackson, M. H. Cosh, T. Zhao, P. E. O'Neill, "Global soil moisture from the Aquarius satellite description and initial assessment," IEEE Geoscience and Remote Sensing Letters, 12(5):923-927, doi: 10.1109/LGRS.2014.2364151, 2015.

[11] Chan, S., R. Bindlish, P. O’Neill, E. Njoku, T. Jackson, A. Colliander, F. Chen, M. Bürgin, S. Dunbar, J. Piepmeier, S. Yueh, D. Entekhabi, M. Cosh, T. Caldwell, J. Walker, X. Wu, A. Berg, T. Rowlandson, A. Pacheco, H. McNairn, M. Thibeault, J. MartínezFernández, Á. González-Zamora, M. Seyfried, D. Bosch, P. Starks, D. Goodrich, J. Prueger, M. Palecki, E. Small, J.C. Calvet, W. Crow, and Y. Kerr, "Assessment of the SMAP Level 2 passive soil moisture product,," IEEE Trans. Geosci. Remote Sens., 54: 49945007, 2016.

[12] Colliander, A., T.J. Jackson, R. Bindlish, S. Chan, N. Das, N., S. Kim, M.H. Cosh, R.S. Dunbar, L., Dang, L. Pashaian, J. Asanuma, K. Aida, A. Berg, T. Rowlandson, D. Bosch, T. Caldwell, K. Caylor, D. Goodrich, H. al Jassar, E. Lopez-Baeza, J. Martínez-Fernández, A. González-Zamora, S. Livingston, H. McNairn, A. Pacheco, M. Moghaddam, C. Montzka, C. Notarnicola, G. Niedrist, T. Pellarin, J. Prueger, J. Pulliainen, K. Rautiainen, J. Ramos, M. Seyfried, P. Starks, Z. Su, Y. Zeng, R. van der Velde, M. Thibeault, W. Dorigo, M. Vreugdenhil, J.P. Walker, X. Wu, A. Monerris, P. E. O’Neill, D. Entekhabii, E. G. Njoku and S. Yueh, "Validation of SMAP surface soil moisture products with core validation sites," Remote Sensing of Environment, in review. 